\title{
Perbedaan Pemahaman Matematis Ditinjau Gaya Kognitif dan Gender Siswa Kelas VII SMPN 12 Kendari
}

(Differences in Mathematical Understanding Reviewed Cognitive and Gender Styles Of Grade VII Students of State Middle School 12 Kendari)

\author{
Aprilia Ayu Nita ${ }^{1}$, Fahinu ${ }^{2} \&$ Busnawir $^{3}$ \\ ${ }^{1}$ Program PascaSarjana Pendidikan MatematikaUHO;email: apriliaayunita20@gmail.com \\ ${ }^{2}$ Pendidikan Matematika FKIP dan PPs UHO;email: fahinu@uho.ac.id \\ ${ }^{3}$ Pendidikan Matematika FKIP dan PPs UHO;email: busna02@yahoo.co.id
}

\begin{abstract}
Abstrak: Penelitian ini bertujuan untuk: (1) Untuk mengetahui gaya kognitif siswa SMP Negeri 12 Kendari, (2) Untuk mengetahui pemahaman matematis siswa SMP Negeri 12 Kendari, (3) Untuk mengetahui perbedaan pemahaman matematis siswa ditinjau dari gaya kognitif field dependent dan gaya kognitif filed independent, (4) Untuk mengetahui perbedaan pemahaman matematis siswa ditinjau dari gender dan (5) Untuk mengetahui perbedaan pemahaman matematis siswa ditinjau dari gaya kognitif dan gender. Jenis penelitian ini adalah penelitian ex post facto.Teknik pengumpulan data menggunakan tes pemahaman matematis dan tes GEFT. Hasil penelitian sebagai berikut: (1) Terdapat perbedaan pemahaman matematis siswa ditinjau dari gaya kognitif field dependent dan gaya kognitif filed independent, (2) Tidak ada perbedaan pemahaman matematis siswa ditinjau dari gender. (3) Tidak ada perbedaan pemahaman matematis siswa ditinjau dari gaya kognitif dan gender.
\end{abstract}

Kata kunci: Gaya Kognitif, Gender, Pemahaman Matematis

\begin{abstract}
This study aims to: (1) To find out the cognitive style of students of state middle school 12 Kendari, (2) To know the mathematical understanding of students of state middle school 12 Kendari, (3) To find out the differences in mathematical understanding students are reviewed from field dependent cognitive styles and cognitive styles filed independently, (4) To find out the differences in mathematical comprehension students reviewed from gender and (5) To know the differences in mathematical understanding of students reviewed from cognitive and gender styles. This type of research is ex post facto research. Data collection techniques use mathematical comprehension tests and GEFT tests. The results of the study were as follows: (1) There were differences in the mathematical comprehension of students reviewed from field dependent cognitive styles and cognitive styles filed independently, (2) There were no differences in the mathematical comprehension of students reviewed from gender. (3) No difference in students' mathematical understanding is reviewed from cognitive and gender styles.
\end{abstract}

Keywords: Cognitive Style, Gender, Mathematical Understanding

\section{PENDAHULUAN}

Matematika merupakan mata pelajaran yang terurut, bertingkat dan berkelanjutan. Apabila siswa menguasai konsep materi prasyarat maka siswa akan mudah untuk memahami konsep materi selanjutnya. Hal yang menjadi permasalahan dalam penyampaian konsep baru yang masih berkaitan dengan konsep materi sebelumnya adalah perbedaan pemahaman konsep dasar yang telah ada dalam pikiran siswa. Konsep siswa menjadi penentu untuk penguasaan materi selanjutnya. 
Dalam pembelajaran matematika, pemahaman matematis sangat penting karena apabila telah dikuasai siswa, maka siswa akan dengan mudah untuk memahami konsep materi yang akan disampaikan oleh guru. Selanjutnya, siswa yang memahami konsep juga akan mampu menyelesaikan berbagai bentuk problem solving yang diberikan. Namun permasalahan yang dialami guru saat ini yaitu siswa masih mengalami kesulitan dalam memahami konsep-konsep matematika sehingga lamban dalam proses menyelesaikan problem solving matematika.

Kemampuan pemahaman matematis terdiri dari pemahaman matematis instrumental dan pemahaman matematis relasional. Kebanyakan pendidik lebih memilih untuk mengajarkan pemahaman instrumental, karena mereka beranggapan bahwa pembelajaran matematika yang menekankan pada pemahaman instrumental relatif lebih mudah. Para guru memilih untuk mengajarkan pemahaman matematis hanya pada level instrumental didasarkan pada salah satu atau beberapa alasan berikut ini: pemahaman relasional memerlukan waktu yang lebih lama untuk mencapainya, pemahaman relasional untuk topik-topik tertentu terlalu sulit, kemampuan relasional dibutuhkan untuk digunakan pada pelajaran lainnya. Pemahaman relasional dinilai lebih sulit dibandingkan dengan pemahaman instrumental, tetapi memiliki beberapa keuntungan salah satunya lebih mudah untuk diadaptasikan pada persoalan baru dan lebih mudah untuk diingat (Syarifah, 2017: 63).

Banyak siswa yang mampu menyelesaikan suatu masalah dengan tingkat koneksi matematis tinggi, tetapi tidak sedikit pula siswa yang bingung dalam menjelaskan pernyataan yang dipilih sebagai jawaban dari permasalahan tersebut. Hal ini dikarenakan dalam pembelajaran hanya menampilkan prosedur rutin dengan menggunakan suatu rumus tertentu tanpa memahami konsep dari materi tersebut, sehingga sulit untuk menghubungkannya dengan konteks nyata. Kemampuan ini merupakan kemampuan pemahaman instrumental, sedangkan dalam menjelaskan mengapa dipilih proses maupun pernyataan tersebut sebagai penyelesaian masalah dituntut kemampuan pemahaman relasional. Meskipun demikian, kemampuan pemahaman instrumental dan kemampuan pemahaman relasional keduanya merupakan bagian dari indikator kemampuan pemahaman matematis yang perlu ditingkatkan dalam pembelajaran matematika.

Proses berpikir siswa dalam penyelesaian masalah matematika dengan menggunakan pemahaman matematis yang dimiliki oleh setiap siswa berbeda. Perbedaan tersebut salah satunya, kemampuan mereka dalam menerima dan memproses informasi yang telah diberikan oleh guru ketika proses pembelajaran berlangsung. Kemampuan ini disebut gaya kognitif. Nasriadi (2016: 16) bahwa salah satu faktor siswa yang penting untuk diperhatikan untuk diperhatikan guru pada 
pembelajaran adalah gaya kognitif. Dimensi gaya kognitif, menurut Al-Salameh (2011: 189) yang digunakan dalam dunia pendidikan adalah gaya kognitif FieldDependent dan gaya kognitif Field-Independent. Rostampour \& Niroomand (2014: 52) individu Field-Dependent sebagai individu yang lebih ramah dan lebih tegas serta memandang perasaan dan pemikiran orang lain dan individu Field-Independent sebagai individu yang dingin dan individualistis. Selain itu, ada faktor lain yang tidak kalah penting yaitu faktor gender.

Muawanah (2009: 2) menyatakan bahwa secara terminologi, gender diartikan sebagai konsep yang berkaitan dengan peran laki-laki dan perempuan disuatu waktu budaya tertentu yang dikonstruksi secara sosial bukan secara biologis. Kimura dan Hampson dalam Jensen (2011: 46) menyatakan bahwa laki-laki dan perempuan memiliki cara yang sangat berbeda dalam mendekati dan menyelesaikan masalah, khususnya dalam pembelajaran matematika. Hal tersebut dipengaruhi oleh belahan otak kanan siswa laki-laki mempunyai kemampuan yang lebih kuat dibidang numerik dan logika daripada belahan otak kanan siswa perempuan. Sedangkan belahan otak kiri siswa perempuan mempunyai kelebihan dibidang estetika dan religius daripada belahan otak kiri siswa laki-laki.Berdasarkan uraian yang telah di kemukakan, maka masalah yang diteliti adalah perbedaan pemahaman matematis siswa ditinjau dari gaya kognitif dan gender.

\section{METODE PENELITIAN}

Penelitian dilaksanakan di SMP Negeri 12 Kendari. Penelitian ini dilakukan terhadap siswa kelas VII pada tahun ajaran 2020/2021 di semester ganjil. Jenis penelitian yang digunakan adalah Ex Post Facto (Emzir, 2008: 119).

Populasi adalah kelas VII pada SMP Negeri 12 Kendari yang terdaftar pada semester ganjil tahun ajaran 2020/2021. Penentuan sampel dalam penelitian ini dilakukan dengan menggunakan teknik Proportional Random Sampling dimana jumlah sampel pada masing-masing strata sebanding dengan jumlah anggota populasi pada masing-masing stratum populasi (Yusuf, 2014: 162).

Desain yang digunakan pada penelitian ini adalah desain treatment by level $2 \times 2$ sebagai berikut:

Tabel 1.

Desain Treatment by Level 2 × 2

\begin{tabular}{lcc}
\hline \multirow{2}{*}{ Gaya Kognitif $(\mathbf{A})$} & \multicolumn{2}{c}{ Gender $(\mathbf{B})$} \\
\cline { 2 - 3 } & Laki-laki $\left(\mathbf{B}_{1}\right)$ & Perempuan $\left(\mathbf{B}_{2}\right)$ \\
\hline field dependent $\left(\mathrm{A}_{1}\right)$ & $\mathrm{A}_{1} \mathrm{~B}_{1}$ & $\mathrm{~A}_{1} \mathrm{~B}_{2}$ \\
field independent $\left(\mathrm{A}_{2}\right)$ & $\mathrm{A}_{2} \mathrm{~B}_{1}$ & $\mathrm{~A}_{2} \mathrm{~B}_{2}$ \\
\hline
\end{tabular}


Keterangan:

$\mathrm{A}_{1} \mathrm{~B}_{1}=$ Kelompok siswa laki-laki dengan gaya kognitif field dependent

$\mathrm{A}_{1} \mathrm{~B}_{2}=$ Kelompok siswa perempuan dengan gaya kognitif field dependent

$\mathrm{A}_{2} \mathrm{~B}_{1}=$ Kelompok siswa laki-laki dengan gaya kognitif field independent

$\mathrm{A}_{2} \mathrm{~B}_{2}=$ Kelompok siswa perempuan dengan gaya kognitif field independent

Instrumen yang digunakan dalam penelitian ini adalah tes gaya kognitif dan tes pemahaman matematis. Tes gaya kognitif siswa pada penelitian diukur dengan instrumen standar untuk gaya kognitif yaitu Group Embedded Figure Test (GEFT). GEFT terdiri dari 3 tahap dengan total waktu selama 15 menit. Tahap pertama, terdiri dari 7 butir soal, tahap kedua dan ketiga masing-masing terdiri dari 9 butir soal. Untuk tahap pertama, siswa diberikan waktu mengerjakan GEFT maksimal 3 menit. Pada tahap kedua dan ketiga, siswa diberikan waktu maksimal untuk mengerjakan masing-masing 6 menit.Adapun kriteria skor pemahaman matematis menggunakan pedoman penskoran yang disajikan pada Tabel 2.

Tabel 2.

Pedoman Kategori Penskoran Gaya Kognitif

\begin{tabular}{cc}
\hline KATEGORI & SKOR \\
\hline Field Dependent & $0 \leq$ skor $<10$ \\
Field Independent & $10 \leq$ skor $\leq 18$ \\
\hline & (Widodo, 2016: 37-39)
\end{tabular}

Adapun kriteria skor pemahaman matematis disajikan pada Tabel 3.

Tabel 3.

Pedoman Penskoran Pemahaman Matematis Instrumental Siswa

\begin{tabular}{llc}
\hline \multicolumn{1}{c}{ Indikator } & \multicolumn{1}{c}{ Keterangan } & Skor \\
\hline Mengintepretasikan & $\begin{array}{l}\text { Tidak mampu mengingat sifat-sifat konsep yang } \\
\text { telah dipelajari dan tidak mampu merumuskan dan }\end{array}$ & 0 \\
dan dapat & memanipulasi konsep & \\
menerapkan rumus & Hanya mampu mengingat sifat-sifat konsep yang & 1 \\
dalam perhitungan & telah dipelajari & \\
sederhana dan & Jawaban salah dimana siswa mampu mengingat & \\
mengerjakan & sifat-sifat konsep yang telah dipelajari dan mampu & 2 \\
perhitungan secara & merumuskan dan memanipulasi konsep tetapi & \\
algoritmik & sangat terbatas dimana siswa mampu mengingat & \\
(Pemahaman & Jawaban benar dimana & \\
Instrumental). & sifat-sifat konsep yang telah dipelajari dan mampu & 3 \\
& merumuskan dan memanipulasi konsep, & \\
& perhitungan secara umum benar namun & \\
\hline
\end{tabular}


mengandung sedikit kesalahan

Jawaban sangat benar dimana siswa mampu mengingat sifat-sifat konsep yang telah dipelajari dan mampu merumuskan dan memanipulasi konsep secara lengkap dan benar

Tabel 4.

Pedoman Penskoran Pemahaman Matematis Relasional Siswa

\begin{tabular}{|c|c|c|}
\hline Indikator & Keterangan & Skor \\
\hline $\begin{array}{l}\text { Mengaitkan satu } \\
\text { konsep dengan } \\
\text { konsep yang lain } \\
\text { (Pemahaman } \\
\text { Relasional). }\end{array}$ & $\begin{array}{l}\text { Tidak mengaplikasikan } \begin{array}{c}\text { konsep } \\
\text { menyelesaikan masalah }\end{array} \text { sehari-hari } \\
\text { menganalisis masalah dalam kehidupan sehari-hari. } \\
\text { Hanya mengaplikasikan konsep dalam } \\
\text { menyelesaikan masalah sehari-hari. } \\
\text { Jawaban salah dimana siswa mengaplikasikan } \\
\text { konsep dalam menyelesaikan masalah sehari-hari } \\
\text { serta menganalisis masalah dalam kehidupan } \\
\text { sehari-hari, tetapi sangat terbatas } \\
\text { Jawaban benar dimana siswa mengaplikasikan } \\
\text { konsep dalam menyelesaikan masalah sehari-hari } \\
\text { serta menganalisis masalah dalam kehidupan } \\
\text { sehari-hari, perhitungan secara umum benar namun } \\
\text { mengandung sedikit kesalahan } \\
\text { Jawaban sangat benar dimana siswa } \\
\text { mengaplikasikan konsep dalam menyelesaikan } \\
\text { masalah sehari-hari serta menganalisis masalah } \\
\text { dalam kehidupan sehari-hari secara lengkap dan } \\
\text { benar }\end{array}$ & 3 \\
\hline
\end{tabular}

\section{HASIL PENELITIAN}

\section{Analisis Deskriptif}

Analisis deskriptif memberikan gambaran terkait setiap variabel dalam penelitian ini. Berdasarkan hasil tes GEFT gambaran terkait gaya kognitif dan gender sampel penelitian diperlihatkan pada Tabel 5 dan Tabel 6 berikut:

Tabel 5.

Data Gaya Kognitif Siswa Kelas VII SMP Negeri 12 Kendari Kognitif

\begin{tabular}{cccccc}
\hline & & Frequency & Percent & Valid Percent & Cumulative Percent \\
\hline Valid & Dependent & 26 & 50,0 & 50,0 & 50,0 \\
& Independent & 26 & 50,0 & 50,0 & 100,0 \\
& Total & 52 & 100,0 & 100,0 & \\
\hline
\end{tabular}

Perbedaan Pemahaman Matematis Ditinjau Gaya Kognitif dan Gender Siswa Kelas VII SMPN 12 Kendari(Aprilia Ayu Nita, Fahinu dan Busnawir) 
Tabel 6.

Data Gender Siswa Kelas VII SMP Negeri 12 Kendari

\begin{tabular}{ccccc}
\hline \multicolumn{5}{c}{ Gender } \\
\hline & Frequency & Percent & Valid Percent & Cumulative Percent \\
\hline Valid laki-laki & 26 & 50,0 & 50,0 & 50,0 \\
perempuan & 26 & 50,0 & 50,0 & 100,0 \\
Total & 52 & 100,0 & 100,0 & \\
\hline
\end{tabular}

Berdasarkan tabel tersebut diketahui bahwa sebagian besar siswa kelas VII SMP Negeri 12 Kendari termasuk dalam kelompok Field Dependent yaitu sebanyak 26 siswa dengan persentase 50\%, sedangkan 26 siswa termasuk dalam kelompok Field Independent. Selain itu, siwa laki-laki dan siswa perempuan berjumlah sama yaitu 26 orang. Hasil analisis deskriptif data pemahaman matematis siswa kelas VII SMP Negeri 12 Kendari yang meliputi nilai minimum, nilai maksimum, rata-rata (mean), nilai tengah (median), dan simpangan baku (standar deviasi) diperlihatkan pada tabel 7

Tabel 7.

Deskriptif Statistik

\begin{tabular}{|c|c|c|c|c|c|c|c|}
\hline \multicolumn{7}{|c|}{ Descriptive Statistics } \\
\hline & Minimum & Maximum & \multirow{2}{*}{ Saxian } & Sum & \multicolumn{2}{|c|}{ Mean } & $\begin{array}{c}\text { Std. } \\
\text { Deviation }\end{array}$ \\
\cline { 2 - 8 } & Statistic & Statistic & & Statistic & Statistic & $\begin{array}{c}\text { Std. } \\
\text { Error }\end{array}$ & Statistic \\
\hline Pemahaman & 7,14 & 64,28 & 42,85 & 2042,60 & 39,2808 & 2,47731 & 17,86417 \\
\cline { 3 - 8 } & & & & & &
\end{tabular}

Disajikan dalam bentuk diagram pada gambar

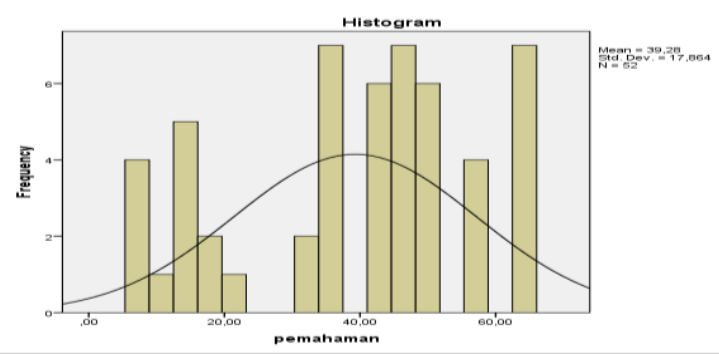

Gambar 1. Deskriptif Statistik

Berdasarkan data yang ditunjukkan pada tabel dan gambar diatas, dapat disimpulkan bahwa data hasil tes pemahaman matematis siswakelas VII SMP Negeri 12 Kendari bervariasi dimana nilai terendah adalah 7,14 sampai dengan nilai tertinggi adalah 64,28 . 


\section{Pemahaman Matematis Siswa Laki-Laki dan Gaya Kognitif Field Dependent}

Data kemampuan pemahaman matematis laki-laki kelas VII SMP Negeri 12 Kendari yang memiliki gaya kognitif field dependet dapat dilihat pada tabel 8 berikut:

Tabel 8.

Data kemampuan Pemahaman Matematis Laki-Laki Yang Memiliki Gaya Kognitif Field Dependent

\begin{tabular}{cccc}
\hline No & Nilai & Frek. Absolut & Frek. Relatif (\%) \\
\hline 1 & 7,14 & 2 & 15,4 \\
2 & 14,28 & 3 & 23 \\
3 & 17,85 & 1 & 7,7 \\
4 & 32,14 & 2 & 15,4 \\
5 & 35,71 & 2 & 15,4 \\
6 & 46,42 & 1 & 7,7 \\
7 & 57,14 & 1 & 7,7 \\
8 & 64,28 & 1 & 7,7 \\
\hline \multicolumn{2}{c}{ Jumlah } & 13 & $100 \%$ \\
\hline
\end{tabular}

Berdasarkan tabel distribusi diatas, dapat dilihat bahwa kemampuan pemahaman matematis laki-laki kelas VII SMP Negeri 12 Kendari yang memiliki gaya kognitif field dependet yang paling banyak pada nilai 14,28 yaitu sebesar 23\% dari grafik dapat dikatakan bahwa nilai cenderung tersebar pada nilai rendah.

\section{Pemahaman Matematis Siswa Perempuan dan Gaya Kognitif Field Dependent}

Data kemampuan pemahaman matematis perempuan yang memiliki gaya kognitif field dependet dapat dilihat pada tabel 9 berikut:

Tabel 9.

Pemahaman Matematis Siswa Perempuan dan Gaya Kognitif Field Dependenta

\begin{tabular}{cccc}
\hline No & Nilai & Frek. Absolut & Frek. Relatif $(\%)$ \\
\hline 1 & 7,14 & 2 & 15,4 \\
2 & 10,71 & 1 & 7,7 \\
3 & 14,28 & 2 & 15,4 \\
4 & 17,85 & 1 & 7,7 \\
5 & 21,42 & 1 & 7,7 \\
6 & 35,71 & 1 & 7,7 \\
7 & 46,42 & 1 & 7,7 \\
8 & 50 & 2 & 15,4 \\
9 & 57,14 & 1 & 7,7 \\
10 & 64,28 & 1 & 7,7 \\
\hline \multicolumn{2}{c}{ Jumlah } & 13 & $100 \%$ \\
\hline
\end{tabular}


Berdasarkan tabel distribusi diatas, dapat dilihat bahwa kemampuan pemahaman matematis perempuan kelas VII SMP Negeri 12 Kendari yang memiliki gaya kognitif field dependent yang paling banyak pada nilai 7.14, 14.28, dan 50 yaitu sebesar $15,4 \%$ dari grafik dapat dikatakan bahwa nilai cenderung tersebar pada nilai rendah dan sedang.

\section{Pemahaman Matematis Siswa Laki-Laki dan Gaya Kognitif Field Independent}

Data kemampuan pemahaman matematis laki-laki kelas VII SMP Negeri 12 Kendari yang memiliki gaya kognitif field independet dapat dilihat pada tabel 10 berikut:

\section{Tabel 10}

Pemahaman Matematis Siswa Laki-Laki dan Gaya Kognitif Field Independent

\begin{tabular}{cccc}
\hline No & Nilai & Frek. Absolut & Frek. Relatif (\%) \\
\hline 1 & 35,71 & 2 & 15,4 \\
2 & 42,85 & 4 & 30,8 \\
3 & 46,42 & 2 & 15,4 \\
4 & 50 & 2 & 15,4 \\
5 & 57,14 & 1 & 7,7 \\
6 & 64,28 & 2 & 15,4 \\
\hline \multicolumn{2}{r}{ Jumlah } & 13 & $100 \%$ \\
\hline
\end{tabular}

Berdasarkan tabel distribusi diatas, dapat dilihat bahwa kemampuan pemahaman matematis laki-laki kelas VII SMP Negeri 12 Kendari yang memiliki gaya kognitif field independet yang paling banyak pada nilai 42,85 yaitu sebesar $30,8 \%$ dari grafik dapat dikatakan bahwa nilai cenderung tersebar pada nilai sedang.

\section{Pemahaman Matematis Siswa Perempuan dan Gaya Kognitif Field Independent}

Data kemampuan pemahaman matematis perempuan kelas VII SMP Negeri 12 Kendari yang memiliki gaya kognitif field independet dapat dilihat pada tabel 11 berikut:

\section{Tabel 11}

Pemahaman Matematis Siswa Perempuan dan Gaya Kognitif Field Independent

\begin{tabular}{cccc}
\hline No & Nilai & Frek. Absolut & Frek. Relatif (\%) \\
\hline 1 & 35,71 & 2 & 15,4 \\
2 & 42,85 & 2 & 15,4 \\
3 & 46,42 & 3 & 23,1 \\
4 & 50 & 2 & 15,4 \\
5 & 57,14 & 1 & 7,7 \\
6 & 64,28 & 3 & 23,1 \\
\hline \multicolumn{2}{c}{ Jumlah } & 13 & $100 \%$ \\
\hline
\end{tabular}


Berdasarkan tabel distribusi diatas, dapat dilihat bahwa kemampuan pemahaman matematis perempuan kelas VII SMP Negeri 12 Kendari yang memiliki gaya kognitif field independet yang paling banyak pada nilai 46.42, dan 64,28 yaitu sebesar $15,4 \%$ dari grafik dapat dikatakan bahwa nilai cenderung tersebar pada nilai sedang.

\section{Analisis Inferensial}

Analisis inferensia dengan menggunakan anava dua jalur. Sebelum melakukan pengujian hipotesis dengan menggunakan anava dua jalur, terlebih dahulu dilakukan pengujian normalitas dan homogenitas. Pengujian normalitas menggunakan uji Kolmogorov-Smirnov dengan tingkat signifikansi yang ditentukan yaitu $\alpha=5 \%$. Keputusan diambil dengan syarat jika nilai Asymp.Sig. (2-Tailed) $>\alpha$ = 0,05, maka terima $\mathrm{H}_{0}$ diartikan data berdistribusi normal dan jika nilai Asymp.Sig. (2-Tailed) $\leq \alpha=0,05$, maka tolak $\mathrm{H}_{0}$ diartikan data tidak berdistribusi normal. Uji homogenitas dilakukan untuk mengetahui apakah data kelompok daridua atau lebih dari populasi yang sama atau tidak. Dalam penelitian ini uji homogenitas dilakukan dengan uji Barlett dengan bantuan SPSS 23.

Diperoleh hasil semua data dari tiap kelompok siswa berdistribusi normal, dikarenakan semua nilai signifikansi dari tiap kelompok > 0,05. Berdasarkan hasil uji homogenitas yang ditunjukkan data homogen.

\section{Uji Hipotesis}

\section{Perbedaan Gaya Kognitif, Gender dan Interaksinya}

Perbedaan rata-rata pemahaman matematis siswa kelas VII SMP Negeri 12 Kendari dari masing-masing kelompok dapat diketahui dengan statistik uji F. Adapun ditampilkan tabel 12 sebagai berikut:

\begin{tabular}{|c|c|c|c|c|c|c|}
\hline \multicolumn{7}{|c|}{ Tests of Between-Subjects Effects } \\
\hline \multicolumn{7}{|c|}{ Dependent Variable: pemahaman } \\
\hline Source & $\begin{array}{l}\text { Type III Sum } \\
\text { of Squares }\end{array}$ & df & $\begin{array}{l}\text { Mean } \\
\text { Square }\end{array}$ & $\mathbf{F}$ & Sig. & $\mathbf{F}_{\text {tabel }}$ \\
\hline Corrected Model & $4707,293^{\mathrm{a}}$ & 3 & 1569,098 & 6,511 & 0,001 & \\
\hline Intercept & 80234,899 & 1 & 80234,899 & 332,917 & 0,000 & \\
\hline Kognitif (A) & 4670,986 & 1 & 4670,986 & 19,381 & 0,000 & 4,04 \\
\hline Gender (B) & 35,327 & 1 & 35,327 & 0,147 & 0,704 & 4,04 \\
\hline kognitif * gender & 0,980 & 1 & 0,980 & 0,004 & 0,949 & 4,04 \\
\hline Error & 11568,269 & 48 & 241,006 & & & \\
\hline Total & 96510,461 & 52 & & & & \\
\hline Corrected Total & 16275,562 & 51 & & & & \\
\hline
\end{tabular}


Berdasarkan tabel diatas, diperoleh hasil berikut:

1. Perbedaan antar A (kognitif)

$\mathrm{F}(\mathrm{A})=19,381>\mathrm{F}_{\mathrm{t}}=4,04$ maka $\mathrm{H}_{0}$ ditolak, artinya terdapat perbedaan rata-rata pemahaman matematis siswa antara gaya kognitif field dependent dan gaya kognitif field independent

2. Perbedaan antar $\mathrm{B}$ (gender)

$\mathrm{F}(\mathrm{A})=0,147<\mathrm{F}_{\mathrm{t}}=4,04$ maka $\mathrm{H}_{0}$ diterima, artinya tidak ada perbedaan ratarata pemahaman matematis siswa antara gender laki-laki dan gender perempuan

3. Pengaruh Interaksi $A B$

$\mathrm{F}(\mathrm{AB})=0,004<\mathrm{F}_{\mathrm{t}}=4,04$ maka $\mathrm{H}_{0}$ diterima, artinya tidak ada pengaruh interaksi antara gaya kognitif dan gender terhadap pemahaman matematis siswa

\section{PEMBAHASAN}

Hasil penelitian menunjukkan bahwa pemahaman matematis yang ditinjau dari gaya kognitif baik dari segi field dependent maupun field independent memiliki pengaruh yang signifikan, terlihat dari uji $F$ dimana $F(A)=19,381>F_{t}=4,04$ maka $\mathrm{H}_{0}$ ditolak, artinya terdapat perbedaan rata-rata pemahaman matematis siswa antara gaya kognitif field dependent dan gaya kognitif field independent. Hasil ini didukung berdasarkan teori yang ada bahwa gaya kognitif siswa memiliki dua jenis dilihat dari aspek kajian psikologi yaitu field dependent dan field independent dimana menggambarkan cara setiap siswa dalam menentukan sikap, cara berpikir dan cara menyelesaikan masalah.Setiap siswa memiliki gaya kognitif yang berbeda dalam menghadapi atau memproses suatu tugas dan masalah. Perbedaan ini bukan menunjukkan tingkat intelegensi tertentu, karena setiap siswa yang berbeda dengan gaya kognitif sama belum tentu memiliki intelegensi yang sama pula. Sehingga siswa yang berbeda dengan gaya kognitif yang dimiliki kemungkinan akan memiliki kemampuan yang juga jauh berbeda.

Siswa yang memiliki gaya kognitif field independent lebih mandiri dengan mengutamakan kemampuan analitik dan sistematis, sebaliknya siswa yang memiliki gaya kognitif field dependent berpikir secara global sehingga cenderung mengikuti dan tidak membutuhkan pemikiran secara analitik dan sistematis. Adanya perbedaan pemahaman matematis yang ditinjau dari gaya kogntif siswa mengisyaratkan bahwa penting untuk seorang guru untuk memperhatikan gaya kognitif yang dimiliki oleh siswanya dalam merancang suatu proses pembelajaran. Siswa pun juga harus mengetahui gaya kognitif yang mereka miliki agara dapat menentukan cara belajar yang terbaik untuk diri mereka baik itu disekolah maupun dirumah.

Namun, dalam pemahaman matematis yang ditinjau dari gender tidak memiliki perbedaan. Begitu pula, dengan pemahaman matematis yang ditinjau dari 
gaya kognitif dan gender. Hal ini dapat dilihat dari hasil gaya kognitif field dependent perempuan lebih kearah nilai rendah dan sedang; untuk gaya kognitif field independent perempuan lebih kearah nilai sedang. Gaya kognitif field dependent laki-laki lebih kearah nilai rendah; untuk gaya kognitif field independent laki-laki lebih kearah nilai sedang. Tidak adanya perbedaan yang signifikan dari hasil tersebut yang ditinjau dari gaya kognitif maupun gendernya.

Dalam hal pembelajaran matematika, perbedaan antara laki-laki dan perempuan sangat tipis bahkan tidak ada perbedaan. Namun dari segi karakteristiknya jika ditinjau dari segi biologis, dan psikologis bahwa laki-laki dan perempuan pada dasarnya memang berbeda. Hal ini mungkin dikarenakan pada era revolusi industri 4.0 dimana dalam era ini mengubah cara pandang tentang pendidikan. Perubahan yang dilakukan bukan hanya sekadar cara mengajar namun pendidikan setidaknya harus mampu menyiapkan anak didiknya menghadapi tiga hal: a) menyiapkan anak untuk bisa bekerja yang pekerjaannya saat ini belum ada; b) menyiapkan anak untuk bisa menyelesaikan masalah yang masalahnya saat ini belum muncul, dan c) menyiapkan anak untuk bisa menggunakan teknologi yang sekarang teknologinya belum ditemukan. Era revolusi industri 4.0 disini menunjukkan cara seorang siswa memahami suatu materi pembelajaran tergantung dari cara siswa tersebut memahami cara belajarnya, bukan berdasarkan gender dari siswa tersebut.

\section{KESIMPULAN}

Berdasarkan hasil penelitian dan pembahasan pada bab sebelumnya, dapat disimpulkan beberapa hal sebagai berikut.

1. Terdapat perbedaan pemahaman matematis siswa ditinjau dari gaya kognitif field dependent dan gaya kognitif filed independent. Terlihat dari uji $\mathrm{F}$ dimana $\mathrm{F}$ (gaya kognitif $)=19,381>\mathrm{Ft}=4,04$ maka H0 ditolak, artinya terdapat perbedaan rata-rata pemahaman matematis siswa antara gaya kognitif field dependent dan gaya kognitif field independent.

2. Tidak ada perbedaan pemahaman matematis siswa ditinjau dari gender laki-laki dan gender perempuan. Terlihat dari uji $\mathrm{F}$ dimana $\mathrm{F}$ (gender) $=0,147<\mathrm{Ft}=$ 4,04 maka H0 diterima, artinya tidak ada perbedaan rata-rata pemahaman matematis siswa antara gender laki-laki dan gender perempuan.

3. Tidak ada perbedaan pemahaman matematis siswa ditinjau dari gaya kognitif dan gender. Terlihat dari uji $\mathrm{F}$ dimana $\mathrm{F}(\mathrm{AB})=0,004<\mathrm{Ft}=4,04$ maka $\mathrm{H0}$ diterima, artinya tidak ada pengaruh interaksi antara gaya kognitif dan gender terhadap pemahaman matematis siswa 


\section{Daftar Pustaka}

Al-Salameh, E.M. (2011). A Study of Al-Balqa' Applied University Students Cognitive Style. Canadian Center of Science and Education, 4(3), 189-191

Emzir. (2008). Metodologi Penelitian Tindakan. Jakarta: PT. Raja Grafindo Persada.

Jensen, E. (2011). Pembelajaran Berbasis Otak. Jakarta: Indeks.

Muawanah, E. (2009). Pendidikan Gender dan Hak Asasi Manusia. Yogyakarta: Teras.

Nasriadi, A. (2016). Berpikir Reflektif Siswa SMP dalam Memecahkan Masalah Matematika ditinjau dari Perbedaan Gaya Kognitif. NUMERACY, 3(1):1526.

Rostampour \& Niroomand. (2014). Field dependence/Independence Cognitive Styles: Are They Significant At Different Levels Of Vocabulary Knowledge?. International Journal of Education \& Literacy Studies, 2(1): 52-57.

Syarifah, L.L (2017). Analisis Kemampuan Pemahaman Matematis Pada Mata Kuliah Pembelajaran Matematika SMA II. JPPM, 10(2): 57-71

Widodo, B. J. (2016). Analisis Epistemic Cognition Peserta Didik dalam Memecahkan Masalah matematika Ditinjau Dari Gaya Kognitif Field Independent dan Field Dependent. Tesis. Surakarta: UNS.

Yusuf, M. (2014). Metode Penelitian: Kuantitatif, Kualitatif dan Penelitian Gabungan. Jakarta: Kencana. 